Београд

DOI 10.5937/kultura1549084S УДК 305-055.2

070.48КОСМОПОЛИТЕН 070.48БЛИЦ ЖЕНА

оригиналан научни рад

\title{
КОНСТРУКLЦИЈА ПОПИТИИКЕ
} KYЛTYPE KPO3 KOHLEEIT

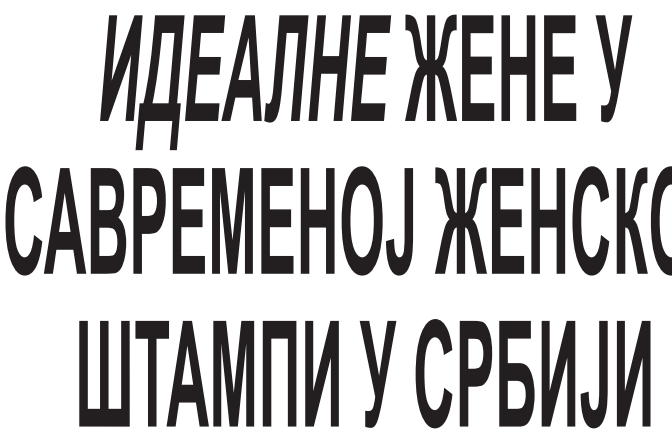

\section{АНАЛИЗА ДИСКУРСА КОСМОПОЛИТЕНА И БЛИЦ ЖЕНЕ}

Сажетак: Рад се бави дискурсом о идеалној жени у Србији данас, односно начином на који је конструисана актуелна политичка култура кроз репрезентацију жена у женским часописима. Покушала сам одредити дискурсе које производе часописи Космополитен и Блии Жена, односно разлике у предложеном концепту женскости, и идентификовати начине на које се ти дискурси и представљаюе жена, юихових родних улога и односа, подударају са ширим друштвеним нормама, стереотипима и праксама. Анализирала сам и општи утисак који остављају часописи и покушала их сместити на основу тога у предложене елементарне прототипе како их назива Неда Тодоровић-Узелаи, у питағу су прототипи модели традиционалне жене-женке и побуњене, ослобођене жене (феминисткиње). 


\section{МИЛИЦА СТАНКОВИЋ}

Кључне речи: концепт идеалне жене, Космополитен, Блии Жена, политичка култура, медијски дискурс, животни стилови, идентиmem

Време и простор у ком живимо карактеришу бројне културне и друштвене промене, али „упркос формалној и законској 'еманципацији', неписани морални кодекс друштава која су била под комунистичком контролом или у транзицији, остао је у суштини патријархалан", ${ }^{1}$ што се огледа пре свега у односу према жени у свим аспектима друштвеног деловања. Иако се свет мења, традиционалне вредности се грчевито држе и опстају, колико кроз православље, које је прилично догматично при подели мушких и женских улога, толико и кроз национализам који је доживео ренесансу у време последњих ратова на овим просторима. Из свега горе наведеног да се закључити да је културни контекст Србије још увек увелико оптерећен патријархалним наслеђем. Све то директно утиче на место и положај жена у друштву, њихову слику о самима себи и наравно на њихове конструкције властитог идентитета.

У ситуацији када, као земља у транзицији, тежимо да прихватимо што више „европских вредности” како би Европа лакше прихватила нас као себи сличне, наше жене одједном бивају принуђене „пливати у мутном”. Како нас традиционална учења ограничавају да будемо апсолутно отворени за новине које стижу из света, тако се прерађују и преобликују идентитети који су сачињени помало од традиције помало од модерног. Оваква ситуација доводи до тога да се у исто време на истом месту јављају различити модели и репрезентације женских улога и модели за њихову идентификацију.

Последњих двадесетак година период је великих промена у друштвеним структурама али и у свим другим аспектима људске културе. Мењају се животни стилови, конструишу се нови тржишно прихватљивији идентитети, па тако наступа криза традиционалних вредности. Најзначајнији период за Србију је управо период после 2000, када доминантне друштвене вредности постају демократске промене и тежња за стварањем једног демократског друштва отвореног за комуникацију са светом и спремног за модернизацију, отварање тржишта и прихватање утицаја са стране (нарочито са Запада). Самим тим отворена је могућност за један нови концепт женскости. Нови понуђени модел „идеалне жене” пласиран је путем медија, кроз филмове, серије, емисије, рекламе и

1 Iveković, I. Neopatrijarhat i političko nasilje; Prilog razumevanju etničkih sukoba na Balkanu i Kavkazu; Republika 174, http://www.yurope.com/zines/ republika/arhiva/97/174/174_12.HTM 
гламурозне лиценциране женске часописе. У том периоду дошло је до преиспитивања дотадашњег пожељног модела, јер измењеном друштвеном контексту, новим друштвеним вредностима које су сада промовисане као пожељне, није више одговарала само представа „идеалне жене” која је до тада била пласирана, а то је пре свега жена домаћица, мајка, супруга (која је подршка свом мушкарцу у свим могућим условима), она која се жртвује за опште добро (за мужа, децу, породицу, државу, веру, нацију). Ове традиционалне пожељне особине жене провлачиле су се кроз фолклорне форме (народне епске песме, приче, игре), кроз националну књижевност, религијску пропаганду, али и популарну културу, народне песме, женске часописе... У новим условима постају пожељне и неке друге карактеристике и пласирају се другачији пожељни обрасци. Социокултурна трансформација српског друштва и културе испољава се пре свега у трансформацији друштвених вредности, која имплицира промену мотива деловања код већине припадника друштва, уношење реда у политички живот, односно у јавно поље, промену политичке културе.

„Политичку културу чине вредности, уверења, убеђења, ставови, симболи, стилови и обрасци политичког деловања и понашања појединца и друштва. Она пресудно утиче на избор циљева и праваца по којима се појединци, друштво и држава креће и развијају."2 И поред свега до значајне промене у концептуализацији женскости ипак није дошло, бар не у општеприхваћеним концептима и идеалним сликама.

Ако обратимо пажњу на положај жене у друштву у Србији данас, приметићемо промену друштвеног контекста први пут почетком 90-тих, кроз ретрадиционализацију, а затим поново након демократских промена 2000. године. Ове последње промене карактерише убрзани продор потрошачке културе, те установљавање друштвених вредности које су специфичне за потрошачко друштво. Све те промене се одражавају на женске родне улоге и на очекивања која жене имају од себе и других. У склопу ових промена је и појављивање како гламурозних лиценцираних женских часописа, од којих је један „Космополитен”, тако и домаћих, који настоје да иду у корак с временом, као на пример „Блиц Жена”.

Медији, међу њима и часописи намењени женама, као једна од кључних друштвених институција, служе као регулативни модел који на неки начин обликује свест жена и промовише одређене пожељне дискурсе и слике према којима се

2 Čupić, Č. (2009) Politička kultura i mediji, Godišnjak Fakulteta političkih nauka, (03), str. 1. 
оне постављају на различите начине или преговарају у процесима конструисања и промене својих идентитета. Према теоријама постмодерности, ми своје системе вредности и разумевања градимо на темељу скупа глобалних информација око нас. Трагање за „правим” или аутентичним ,jа” отвара могућност да се избором животног стила искушава, изражава и креира лични идентитет. Данас се животни стилови првенствено бирају селекцијом оних који се нуде путем медија.

Посредством медија успоставља се однос између различитих страна на основу друштвених и културних вредности. Медији одржавају или конструишу политичку културу друштва, повезују друштвене институције, њихове дискурсе, догађаје који их окружују и публику која чита, гледа или слуша медијске текстове. Зато дискурс медија представља врло интересантно подручје за истраживање пре свега због тога што медији представљају саставни и свеприсутни део наших живота.

Пропаганда је средишња сила у масовним медијима. Рекламе су тако дубоко уклопљене у нашу околину да их константно видимо, чујемо и чак осетимо мирисе (на пример, рекламе за парфеме из неких женских часописа). Постоји широк спектар специфичних порука које указују на везу између производа и животних стилова, између услуга и стања свести - козметика и љубав, одело и успех, храна и задовољство/ незадовољство... Женски часописи повезују женски идентитет са одређеним потрошачким навикама. Без обзира на различитост рекламних порука оно што је заједничко свим рекламама јесте продаја. Рекламе се обраћају гледатељима као потрошачима и оне су најчешће идеолошке природе - peдовно нам говоре да се срећа и задовољство могу купити. У том смислу рекламирање претпоставља културу потрошње. Због узастопног понављања, медијски текстови, па тако и рекламе, намећу одређене друштвене вредности као природне и неизбежне, и одређена уверења и митове о друштвеним идентитетима и културним нормама као универзално примењиве.

Неда Тодоровић-Узелац када говори о женској штампи подразумева „листове чија укупна уређивачка филозофија и садржином и формом (стил и језик „женске штампе”) тежи женском читаоцу. Врста публике којој се ти листови обраћају - други пол - и начин њихове специјализације - 
женственост - помажу јасној дистинкцији таквих новина у односу на остале илустроване, забавно-ревијалне листове.”

На самом почетку свог постојања женски часописи су били нека врста приручника који су садржали упутства о моралном владању, понашању и социјалној етикецији, информације о моди и о томе како да жене најбоље испуне своју улогу - да буду добре супруге и мајке. Настали су „као специфична врста мушких упутстава женама како да живе, како да се понашају, како да буду успешне супруге, мајке и домаћице. Још од тог времена до данас већина женских часописа сводила је женски универзум на приватну сферу, а информације о јавним дешавањима - политика, економија, друштвене теме - биле су ретке и успутне. Од XVIII до XIX века пребацује се тежиште са морално религијског наглашавања женске природе на величање женског рада и постигнућа. Нова „идеална жена” била је првенствено дефинисана као она која „чини кућу” преузимајући практичне (управљање домаћинства), економске (управљање финансијама домаћинства) и моралне дужности (репродукција, нега и одгој). Рад у домаћинству схватан је као организациони принцип женских живота, али у овом периоду убацују се и делови посвећени моди и лепоти. ${ }^{4}$ Џенифер Крејк (Jennifer Craik) када описује овај период каже: „С једне стране, женска улога је била да буде лепа, одевена у одећу која изражава социјални статус њеног мужа или оца, али и сопствену пожељност. Међутим, кућна улога захтевала је да њена сексуалност може бити изражена једино материнством." ${ }^{5}$ До касног XIX века појављује се још један модел женствености - модел жене потрошача, који може да се повеже са појавом индустрије производа намењених лепоти и комерцијализације визуелног у женској штампи. Како су се услови живота жена све више мењали, почетком XX века жена је постала чувар породичног здравља и среће, а не социјалне позиције. Оваква ситуација се огледала у измењеном садржају, који се сада вртео око домаћинства, лепоте, самоусавршавања, моде и социјалне етикеције. „Женска тела (пре него морални квалитети) постала су вредност путем које су могли бити постигнути успеси на различитим сферама. Одећа и силуета тела постали су видљиве ознаке стила.” ${ }^{\mathrm{C}}$ једне стране, часописи сада нуде практичне савете и инструкције о томе

3 Todorović Uzelac, N. (1987) Ženska štampa i kultura ženstvenosti, Beograd Naučna knjiga, str. 5.

4 Craik, J. (1993) The face of fashion. The Cultural Studies in Fashion, London: Routledge, p. 51.

5 Исто, стр. 52.

6 Исто, стр. 55. 
како бити женствена, а са друге стране нуде представе о женствености - моду и лепоту.

Друга „независна развојна линија” женских часописа, како је назива Неда Тодорови-Узелац, била су феминистичка гласила која су издавана упоредо, а била су више информативног и политичког него забавно саветодавног садржаја. Они су се нарочито појављивали у периодима највећих друштвених превирања и својим захтевима су одражавали положај жене на друштвеној позорници одређеног историјског раздобља. За разлику од класичних женских часописа који су инсистирали на женским дужностима, феминистичка штампа се залагала за женска права. Феминистичка гласила су нарочито долазила до изражаја у време ратних збивања. а чак су и класични женски часописи били ангажованији када је требало мобилисати жене да активно допринесу ратним напорима, промовисали су плаћени рад у ратној производњи и волонтерски рад за обнову земље.

Женски часописи и њихова публика постали су предмет академског интереса веома рано. Још је 1963. године Бети Фридан (Betty Friedan) у делу „Женска мистика” критиковала представу „срећне домаћице” коју представљају амерички женски часописи. Критика је сугерисала да ови часописи портретишу површан низ модела женских улога. Понуђене улоге, назначени животни обрасци, понуђени ставови делују као социјални регулатор који обезбеђује статус кво, обликујући женску тачку гледишта и легитимишући недостатак избора за жене. Затим, ту су Џенис Виншип (Janice Winship) $)^{8}$, Наоми Волф (Naomi Wolf) ${ }^{9}$ и други. Данас је медијска репрезентација жене веома интересантна тема за истраживање и полазиште многих истраживачких радова свуда у свету.

Код нас такође постоји академски интерес за не само женске часописе већ уопште за представљања жена у медијима (поред Неде Тодоровић-Узелац, ту су нпр. Мирослава Малешевић, Слободанка Пековић, Анђелка Милић, Марина Благојевић, Сњежана Миливојевић, и друге). Иако су предмет бројних критика, женским часописима се не може оспорити то да на неки начин представљају, али и обликују женску масовну културу, политичку културу одређеног друштва - или да другачије кажемо - женску стварност. Морамо се сложити

7 Friedan, B. (1972) The Feminine Mystique, London: Penguin books.

8 Winship, J. (1988) Inside Women's Magazines, Pandora Press popular culture.

9 Wolf, N. (2002) The Beauty Myth: All Images of Beauty are Use Against Women, New York: Perennial (Harper Collins). 
са чињеницом да женски часописи са својим милионским читалачким аудиторијумом имају огромну одговорност према женама, а њихова моћ лежи пре свега у репрезентацијама жене и њених родних улога које нуде на својим страницама. Сва друштва кроз историју конструишу одређени пожељни модел „идеалне жене” на разне начине. У модерном добу ти пожељни обрасци се најчешће пласирају путем медија, те је тако улога медија у политици репрезентације свакако веома значајна. Они из лепезе могућих идентитета којима је стварност испуњена бирају одређене типове и од њих стварају пожељне обрасце. Ти обрасци формирају оквир на основу кога се „гради заједничко разумевање света и колективни осећај заједништва". ${ }^{10}$ Управо ти пожељни обрасци постају и доминантни обрасци. Међутим, оно што је доминантан модел у једном периоду не значи нужно да је и једини. У мноштву женских часописа данас паралелно егзистирају вредносно различити садржаји, различити пожељни обрасци и ментални модели, и управо то је одраз ситуације у којој се жена у Србији данас налази, она је суочена са захтевима новог времена али је и даље ограничена традиционалним очекивањима. Простор који је посвећен појединим темама у неком часопису, епитети и термини који се најчешће користе, све то води ка производњи слике о томе каква би жена требало да буде и њеном ширењу/наметању. Читајући овакав материјал, особа индиректно ствара слику о себи, о пожељним вредностима у свом животу и у друштву. То онда битно утиче на њен однос према другима, према себи, својој улози у друштву итд.

Анализом дискурса који производе наведени медији настојаћу одговорити на неколико питања: које животне стилове пласирају „Блиц Жена” и „Космополитен”, како ови часописи осликавају жене, како су представљене родне улоге, које су сличности, а које разлике у општем расположењу које се описује у наведеним часописима узимајући у обзир улогу и положај жене у друштву, те који су то животни стилови које наведени часописи предлажу конзументима и који су сегменти живота помоћу којих се жена најбоље остварује као личност и којима остварује свој идентитет.

Да бих утврдила дискурсе којима оперишу часописи „Блиц Жена” и „Космополитен”, користићу текстуалне анализе унутар теоретског оквира Ван Дијкове теорије о дискурсу. Ова метода нагласак ставља на идеологију и спознају и на њихов ефекат на структуру текста онаквог какав је

10 Milivojević, S. Žene i mediji:strategije isključivanja, Genero - časopis za feminističku teoriju, posebno izdanje, ur. Milivojević, S. (2004) Beograd: Ženske studije i komunikacija, Centar za ženske studije, str. 113. 
представљен читаоцу/читатељки. С обзиром на могућност медија да допру до огромног броја људи, нарочиту пажњу треба обратити на дискурс који они производе, јер то утиче на менталне моделе корисника медија. „Путем генерализације и апстракције, међутим, такви модели у исто време могу служити као основа за индиректну контролу над знањем и ставовима који су заједнички за многе или већину чланова групе." ${ }^{11}$ Из овог следи да би анализа медијског дискурса у женским часописима пружила увид у представе и концепте (Ван Дајк би рекао „менталне моделе”), који индиректно утичу на ставове и идеологије.

Кључно питање у анализи најзаступљенијих тема било је на који начин је одређена тема представљена, односно на који начин се она, кроз начин говора о њој, дискурзивно конструише. Анализирала сам и општи утисак који остављају часописи и покушала их сместити на основу тога у предложене ,елементарне прототипе” како их назива Неда Тодоровић-Узелац: „Разматрајући однос 'женске' штампе према њеној публици (и обрнуто) требало би, испитати и фактор идентификације читатељке са, у штампи предложеним и понуђеним моделима. Ова штампа намеће два, елементарна прототипа жене:

- Традиционална жена - женка (првенствено супруга и мајка) која живи у резервату приватности склоњена од суровости спољног (мушког) света;

- Побуњена, ослобођена жена (феминисткиња) која се појављује после седамдесетих година (са неофеминизмом).

Због овакве поделе у целокупну штампу за жене импрегниране су одређене вредности (слике, модели) које иду у истом смеру ка поједностављивању улога полова: мушкарац је готово увек муж, а жена је, углавном у функцији супруге, мајке." 12

Иако ове моделе не можемо посматрати као искључиве, покушаћемо потврдити веровање да „Блиц Жена” приказује и нуди онакву слику жене која би се највише могла сврстати у први (традиционални) прототип, док „Космополитен” нуди модел ослобођене жене, која би се донекле могла сврстати у други прототип. Управо те елементе ћу покушати анализирати, а затим показати да ли су ти дискурси, тзв „наш” и „страни”, „домаћи” и „туђи”, „балкански” и „европски”,

11 Van Dijk, T. A. (1995) The mass media today: Discourses of domination or diversity?, Ljubljana: Javnost-The Public, 2 (2), p. 31., http://www.discourses.org/OldArticles/The\%20mass\%20media\%20today.pdf.

12 Todorović Uzelac, N., nav. delo, str. 124. 
„традиционални” и „модерни”, ${ }^{13}$ заиста потпуно супротстављени, да ли су комплементарни, алтернативни или потпуно искључиви.

Ова два часописа су узета у разматрање с разлогом - „Блиц Жена“ као представник домаћег културног контекста и као најтиражнији домаћи часопис за жене ${ }^{14}$ и „Космополитен“ као представник лиценцираних гламурозних часописа који долазе са Запада, из другачијег културног контекста, који је сам по себи један од најпрепознатљивијих брендова у женској масовној култури и носилац специфичног животног стила који промовише. При томе су на први поглед два потпуно различита часописа, на различите начине се обраћају жени и чини се, нуде другачије моделе за идентификацију. Позицијом из које полазе као да стварају дихотомија Ми Други, односно јаз између „њихове” и „наше” оптике у репрезентацији „идеалне жене”.

Ако упоредимо садржаје „Космополитена” и „Блиц жене” видећемо пре свега да је заступљеност тема веома различита. „Космополитен” нагласак ставља на моду, лепоту и негу, а из таквог става произилази да је лепота императив. Када говори о познатим женама које су узори успеха и које имају могућност да представе своје каријере и да инспиришу читатељке својим изгледом, професионализмом, стилом живота и филозофијом, кроз тему се стално провлачи да су оне пре свега лепе и да добро изгледају. Ово наводи да су лепота и успешна каријера особине које дефинишу жене које приказује часопис. Лепота је апсолутни императив. „Блиц жена” има другачији приступ овој тематици. Лепота јесте важна, али није императив, она се огледа пре свега у „телу и духу” (назив рубрике), здрављу и равнотежи (која се постиже сређеним породичним животом), недостаци се могу прикрити, килограми скинути, а ту је и „Блиц жена” да помогне у томе.

Следећа тема по заступљености у „Космополитену” су односи и везе, те секс. Овде се часопис поставља као психолог који ће растумачити и упутити читатељке у све тајне међуљудских односа, са пријатељима, колегама, партнером. Такође ће их упутити у све „Тајне мушког мозга”, открити како мушкарци размишљају и шта очекују од жена у вези, браку, сексу. Секс се приказује као оруђе за манипулацију и освајање мушкарца, а знање сексуалних техника приказано је као врста капитала чија ће се вредност показати када се

13 Синтагме које се у литератури и јавном говору најчешће употребљавају како би се описала културолошка подвојеност друштва у Србији.

14 http://www.blic.rs/Vesti/Drustvo/186903/Svaki-broj-Blic-zene-ponovo-citamilion-zena. 
помоћу њих ухвати и задржи мушкарац. Овакав сензационалистички начин представљања сексуалних потреба и односа је можда био револуционаран у време када је „Космополитен” „жарио и палио” али тешко да би могао бити такав данас у време када су све информације (па и тог типа) присутне на сваком кораку и нису више табу тема. Овде изгледа да овакав говор о сексу и односима служи само да би одвратио женину пажњу од политички значајних тема.

У „Блиц жени” су секс, везе и односи доста мање процентуално заступљени, а прилази им се из угла информисања и упућивања. Секс се описује у смислу вођења љубави, нема експлицитних описа ни слика. Каријера се у „Космополитену" везује за образовање, самопоуздање и физички изглед, а у „Блиц жени” за судбину, традицију и подршку породице. Једна од тема која показује највеће разлике у заступљености је мајчинство и деца. У „Космополитену” се ова тема помиње ретко, а и то је провучено кроз неку другу причу, док се у „Блиц жени”, поред рубрика које се односе на децу и васпитање, кроз дословно сваки текст провлачи идеја мајчинства, тако да се стиче утисак да је то неизбежан крајњи циљ живота жене. Чак и након хваљења свих професионалних успеха жене, сугерише се да њен живот никада неће бити потпун и испуњен ако не буде мајка. Женама се нуди мит о породици и мајчинству као једини начин самоостварења. Вредност традиционалне породице се подржава и јача, а произведени дискурс игнорише сваку другу алтернативу. У ситуацији када је жена разведена показује се као део шире породице, јер јој је увек потребна помоћ са стране и нечија подршка.

Управо овде бисмо могли да покажемо још један пример блокиране трансформације у Србији, што можемо видети на примеру „Блиц жене”. „На приватном породичном плану долази такође до значајних промена у смеру ретрадиционализације и репатријархализације породичног живота." 15 „Теза о блокираној трансформацији брака (партнерства) потврђена је и у социолошком истраживању Смиљке Томановић и Сузане Игњатовић (2004). Оно је указало на одсуство индивидуализације животних стилова међу младима у Србији, на велику зависност од родитељске породице, те на одлагање свих битних догађаја у животу појединца: завршетак школовања, брака, формирања породице, запослења и економског осамостаљења. При томе, на нормативном

15 Anđelka Milić, A. Porodica i modaliteti radnih aktivnosti članova. Promene u toku post-socijalističke tranzicije u Srbiji, od 1991-2006 godine, u: Društvo u previranju: Sociološke studije nekih aspekata društvene transformacije u Srbiji, ur. Tomanović, S. (2006), Beograd: Institut za sociološka istraživanja Filozofskog fakulteta u Beogradu, str. 61. 
плану, брак и даље задржава инструменталну вредност одрастања и одвајања од породице порекла, тесно се повезује са рађањем, те се само партнерство још увек не перципира као „чист однос”. Тако уместо индивидуализације и еманципације, породице су у Србији захваћене трендом ретрадиционализације, повратка на премодерне обрасце узајамног испомагања и удруживања, а често и натуралне производње и потрошње, а све у циљу голог преживљавања." ${ }^{16}$ Наглашавање породице, мајчинства и уопште традиционалних породичних односа у “Блиц жени” је у складу са друштвеним и културним контекстом Србије, који је и даље увелико оптерећен стереотипним представама не само о месту и положају жене у друштву, већ и о породичним и међуљудским односима уопште.

У модерном друштву примећује се криза и нестајање традиционалних образаца људске повезаности. „Различито од Истока Европе, укључујући и простор Западног Балкана, почев од друге половине XX века па све до данас, развијене државе Запада пролазе кроз битно другачије, корените преображаје брачне дијаде, тј. тежишта породице у диркемовском дискурсу. У суштини те, у крајњој линији, постпатријархалне промене у породици, друштву и култури, је велика трансформација мушко-женских односа, која значи и напуштање дотадашњих уобичајених животних стилова. Промењени су форма и садржај брака и/или партнерства, профамилистичке вредности уступају место индивидуалистичким циљевима самоактуелизације, што значи и перманентно мењање самих индивидуа (self-therapy). Животни ток није више нити униформан, нити се унапред може предвидети антиципирањем животних догађаја, већ је то један веома неизвестан пут на коме треба рефлексивно промишљати претходну биографију и доносити нове одлуке. Демографи Dirk Van de Kaа и Ron Lestheage су сада већ давне 1986. године, сковали парадигму „друге демографске транзиције” којом су обухватили те крупне промене интимности." 17 Управо таква слика међуљудских односа може се препознати у „Космополитену”. Управо на примеру начина приказивања образаца људске повезаности могли бисмо дискурс часописа „Космополитен” одредити као „туђи”, док би дискурс „Блиц жене” у том смислу могао бити посматран као „наш”.

16 Bobić, M. Blokirana transformacija bračnosti u Srbiji - kašnjenje ili izostanak „Druge demografske tranzicije”?, u: Društvo u previranju: Sociološke studije nekih aspekata društvene transformacije u Srbiji, ur. Tomanović, S. (2006), Beograd: Institut za sociološka istraživanja Filozofskog fakulteta u Beogradu, str. 123. i 125.

17 Bobić, M. nav. delo, str. 131. 
Ако покушамо да концепт идеалне жене који нуде „Космополитен” и „Блиц жена” сместимо у један од два предложена модела које предлаже Неда Тодоровић Узелац, видећемо да ни то није лако. Лакше ће нам бити са „Блиц женом”концепт „идеалне жене” који она нуди могао би се сместити под модел “Традиционална жена - женка (првенствено супруга и мајка) која живи у резервату приватности склоњена од суровости спољног (мушког) света", 18 једино што су традиционалној удатој жени са децом додате обавезе - да буде, ако је могуће, запослена изван куће, али и даље добра домаћица, лепа, негована, дотерана, здрава, затегнута и секси, увек на располагању „свом” мушкарцу који је гарант њене даље сигурности и идиличног породичног живота.

„Космополитен” је мало сложенији. Иако његов концепт „идеалне жене” на први поглед изгледа као да представља „побуњену, ослобођену жену (феминисткињу)"19, прилично је далеко од тога. Ослобођење жене као целовите особе ипак не лежи само у савладавању техника секса помоћу којих ће се манипулисати партнером, уместо да га воли, нити се независност и еманципованост стичу што већим бројем партнера. „Космополитен” нуди слику света у ком се жене и мушкарци третирају као ловци и ловина, где се иницијатива односи на умеће завођења, а амбиција на манипулацију другим полом. „Космополитен” се труди да каријера, авантура, храброст, независност и амбиција жене буде увек у некој вези са мушкарцем. У томе не би било ништа лоше када то не би био једини избор и једина права вредност за жене. Сексуална слобода коју нам је „Космополитен” наводно помогао изборити, тек је илузија скривена иза „слободних разговора и савета” који су само мамац за бољу продају производа лајфстајл индустрије и козметичких производа. Хелен Гурли Браун (Helen Gurley Brown) је у интервјуу за хрватски недељник „Национал” изјавила: „Феминистице су ми замјериле да је жена у Cosmopolitanu представљена као сексуални објект, што заправо и није неточно: јер када је жена сексуално привлачна мушкарцу, то је најљепша ствар која јој се може догодити., 20

Дискурзивна текстуална пракса у женским часописима конструише идентитет у складу са општим схватањима која су удружена са експертским профилом „идеалне жене”. Сваки од ова два часописа полази од другачије претпоставке о

18 Тодоровић-Узелац, Н. нав. дело, стр. 14.

19 Исто, стр. 15.

20 Tjednik Nacional, 01. 04. 1998, http://www.nacional.hr/tiskano/arhiva. 
томе каква би требало бити „идеална жена” коју портретише. "Космополитенова" жена изгледа отприлике овако:

- атрактивна, актуелна, активна, амбициозна, са израженим самопоуздањем и ставом, зна што жели и како до тога доћи, саможива, нарцис.

„Блиц Жена” представља жену као:

- лепа, вредна, пожртвована, добра домаћица, мајка, супруга, не истиче се посебно, уредна, смирена, није егоиста.

Употреба лексике у текстуалној пракси у ова два часописа се разликује. У „Космополитеновом” случају комуникација између часописа и његове публике је непосреднија, директнија и провокативнија. Ствари се називају правим именима и често се на неформалан начин говори о „шкакљивим темама”. Стиче се утисак присног односа. „Блиц жена” углавном користи политички коректан начин комуникације који је у складу са друштвеним нормама. Композиција текстова је одређена жанровском припадношћу. Текстови генерално, иако на различите начине, само потврђују оно што су општа места положаја и улоге жене у друштву, без посебног интереса за карактеристичне околности у којима се целокупно друштво налази. Текстуална динамика одређена је како жанром тако и специфичношћу тема које обрађују, а разлике у ова два часописа се виде у приступу проблематици и начину комуникације са публиком. Друштвену спознају можемо описати као везу између семиотичке текстуалне продукције и манифестације неједнакости и подређености. С једне стране стоји дискурс часописа „Космополитен” који конструише представљање жена као амбициозних, оних које преузимају иницијативу, знају шта хоће, а истовремено производи имплицитна представљања која одржавају стереотипне сексистичке перспективе. А са друге дискурс часописа „Блиц жена” који и експлицитно и имплицитно представља жену ограничену на патријархални дискурс кроз који се „значај жене сагледава само кроз улоге супруге, мајке и домаћице, и легитимише њен подређен положај у приватном и јавном домену у односу на мушкарца."21

\section{Закључна разматрања}

Намера овог рада била је пре свега да покаже да анализа дискурзивне конструкције пожељних женских улога у медијима

21 Перишић, Н. (2005) Масовна женска штампа, патријархални дискурси и мртво биће жене, дипломски рад, Одељење за етнологију и антропологију, Филозофски факултет, Универзитет у Београду. 
има једнаку важност као и теме које се односе на класична питања родне проблематике, као што је питање представљања и стереотипизације уопште у одређеном друштву, али и питање формирања и одржавања политичке културе. Анализирајући дискурсе „Космополитена” и „Блиц жене” кроз њихов концепт „идеалне жене” покушала сам уочити како настају и како се конструишу одређени идентитети, логике, режими и њихово практиковање. Иако је централна тема оба ова часописа жена, постоји разлика у дискурсима које производе и у концепту “идеалне жене” који пласирају. Иако се на први поглед стиче утисак да је могуће супротставити ова два дискурса и „Космополитен” поставити у позицију часописа који представља побуњену, ослобођену, еманциповану жену, а „Блиц жену” ставити у позицију која представља традиционални модел жене-женке, ипак то није могуће. Разлике у репрезентацији „идеалне жене” постоје али суштина остаје иста. На крају стичемо утисак да дискурси оба ова часописа на неки начин присиљавају своју публику да наставе са стандардним стереотипима о женама и мушкарцима. Иако само постојање оваквих дискурса не значи да аутори и читатељке нису у могућности увидети која представљања у датом контексту односа моћи имају функцију и улогу родних стереотипа, ипак само постојање милионских и вишемилионских тиража ових часописа наводи на помисао да је утицај који они имају на формирање ставова своје публике веома велик, а самим тим ови дискурси конституишу традиционалне стереотипе о положају и улози жене у друштву. Због тога су они важни и одговорни кад је у питању формирање, ширење и одржавање политичке културе појединца, друштва и државе.

Жене у Србији готово да и не знају да постоји избор другачији од оног који им се свакодневно сервира, а велика већина њих није ни свесна сугестивне манипулације сликама и подтекстом које их уверавају да је оно што им се сервира у ствари оно што саме желе. Могло би се десити да се слике у женским часописима погрешно тумаче, да у недостатку идентитета изван понуђених стереотипних слика, нове генерације девојака и жена буду принуђене и даље прихватати понуђене обрасце и пожељне идеологије из простог разлога јер немају алтернативу. Оваква ситуација наводи на помисао о томе да није довољно само препознати проблем, потребно је и покушати пронаћи решење. Решење овог проблема је управо у алтернативи у облику другачијих медијских образаца за жене које желе нешто више од оваквих понуђених улога које не излазе из оквира стереотипа, за оне које желе истинску еманципацију. Истинску еманципацију доживљавам као, пре свега, могућност избора, апсолутну слободу 
управљања својом судбином ослобођену свих стереотипа, обичаја и друштвених „норми”.

Коначан закључак је да и поред другачијег првог утиска дискурси и „Космополитена” и „Блиц жене” у суштини подржавају идеју подређености жене, ограничености њених улога и могућности деловања. Та „подређеност” жене огледа се у томе што је, на крају крајева, без обзира на то да ли је реч о пожртвованој, скромној, традицији склоној жени или о, како би је „Космополитен” назвао, ААА ослобођеној захтева традиционалне породице, смисао женског живота представљен као трагање за, и проналажење „правог” мушкарца. Изгледа да су томе посвећене све њене активности. Испада да је жена непотпуна ако је сама, јер једино кроз мушкарца може да води смислен и испуњен живот. Оба ова дискурса, а и концепте „идеалне жене” које презентују, могли бисмо окарактерисати као мизогине, и то у смислу како их описује Ивана Кроња: „Мизогинија у јавном медијском простору има више облика, од веома препознатљивих до врло софистицираних. Садржана како у визуелном представљању тако и у дискурсу, који се, према правилу, узајамно допуњују, мизогинија се изражава кроз дискриминацију жена према лепоти, годинама, кроз негирање и умањивање професионалних постигнућа жена, стереотипе о нижој интелигенцији и способностима жена, кроз приказивање освајања мушкараца и елиминисање женске конкуренције као јединог смисла за жене, те кроз упорно и широко заступљено свођење значаја жена на њихов физички изглед и давање женама улоге сексуалних објеката."22

„Космополитен” и „Блиц жена” су само један од примера суптилног провлачења дискриминације жена и стереотипних представа кроз нашу свакодневицу. Изгледа да смо још увек заробљени између промена и традиције. Стереотипне представе о разним аспектима друштвеног деловања, а међу њима и о положају и улози жене, и даље се грчевито држе. А изгледа да смо „талентовани” да од новина усвајамо само оно што нам се уклапа у постојеће норме и вредности. Стереотипи су нам се толико инфилтрирали у стварност да их је често тешко и препознати, а свакодневица нам је пуна општих места и егзистенцијалних проблема, да „од дрвећа не видимо шуму”. Против стереотипа се можемо изборити

22 Kronja, I. Politika u porno ključu: pornografsko predstavljanje žena u tabloidima u Srbiji i njegova politička uloga, u: Rodni stereotipi u medijima: reprezentacija žena u štampanim medijima u Jugoistočnoj Europi, ur. Bamburać, M. N., Jusić, T. i Isanović, A. (2006), Sarajevo: Mediacentra, str. 197, http:// www.mc.rs/stereotipizacija-reprezentacija-zena-u-stampanim-medijima-ujugoistocnoj-evropi.792.html. 
само едукацијом и пружањем могућности избора, а ту ступају на сцену медији, који као витални састојак демократије имају посебну одговорност да промовишу поштовање људског достојанства, борбу против свих облика дискриминације и равноправност на свим нивоима.

\section{ЛИТЕРАТУРА:}

Iveković, I. Neopatrijarhat i političko nasilje; Prilog razumevanju etničkih sukoba na Balkanu i Kavkazu, Republika 174, http://www. yurope.com/zines/republika/arhiva/97/174/174_12.HTM.

Čupić, Č. (2009) Politička kultura i mediji, Godišnjak fakulteta političkih nauka, (03), Beograd.

Todorović-Uzelac, N. (1987) Ženska štampa i kultura ženstvenosti, Beograd: Naučna knjiga.

Craik, J. (1993) The face of fashion. The Cultural Studies in Fashion, London: Routledge.

Friedan, B. (1972) The Feminine Mystique, London: Penguin books.

Winship, J. (1988) Inside Women's Magazines, Pandora Press popular culture.

Wolf, N. (2002) The Beauty Myth: All Images of Beauty are Use Against Women, New York: Perennial (Harper Collins).

Milivojević, S. Žene i mediji:strategije isključivanja, u: Generočasopis za feminističku teoriju, posebno izdanje, ur. Milivojević, S. (2004), Beograd: Ženske studije i komunikacija-Centar za ženske studije.

Van Dijk, T. A. (1995) The mass media today: Discourses of domination or diversity?, Ljubljana:Javnost-The Public, 2(2), http://www. discourses.org/OldArticles/The\%20mass\%20media\%20today.pdf

Anđelka Milić, A. Porodica i modaliteti radnih aktivnosti članova. Promene u toku post-socijalističke tranzicije u Srbiji, od 1991-2006 godine; u: Društvo u previranju: Sociološke studije nekih aspekata društvene transformacije u Srbiji, ur. Tomanović, S. (2006), Beograd: Institut za sociološka istraživanja Filozofskog fakulteta u Beogradu.

Bobić, M. Blokirana transformacija bračnosti u Srbiji - kašnjenje ili izostanak Druge demografske tranzicije?, u: Društvo u previranju: Sociološke studije nekih aspekata društvene transformacije u Srbiji, ur. Tomanović, S. (2006), Beograd: Institut za sociološka istraživanja Filozofskog fakulteta u Beogradu.

Tjednik Nacional, 01. 04. 1998, http://arhiva.nacional.hr/

Перишић, Н. (2005) Масовна женска штампа, патријархални дискурси и мртво биће жене, дипломски рад, Одељење за етнологију и антропологију, Филозофски факултет, Универзитет у Београду. 
Kronja, I. Politika u porno ključu: pornografsko predstavljanje žena u tabloidima u Srbiji i njegova politička uloga, u: Rodni stereotipi u medijima: reprezentacija žena u štampanim medijima u Jugoistočnoj Europi, ur: Bamburać, M. N., Jusić, T. i Isanović, A. (2006), Sarajevo: Mediacentra, http://www.mc.rs/stereotipizacija-reprezentacija-zena-ustampanim-medijima-u-jugoistocnoj-evropi.792.html

\title{
Извори:
}

http://www.cosmopolitan.rs/

http://zena.blic.rs/

http:/www.cosmopolitan-scg.com/index.php?news=6945

http://www.blic.rs/Vesti/Drustvo/186903/Svaki-broj-Blic-zene-ponovo-cita-milion-zena http:/www.blic.rs/stara_arhiva/slobodnovreme/75801/Vodic-za-savremenu-zenu

Construction of political culture through the concept of the ,ideal woman" in contemporary women's magazines in Serbia - analysis of discourse in „Cosmopolitan“ and „Blic žena“" magazines

\author{
Milica Stanković \\ Belgrade
}

\section{CONSTRUCTION OF POLITICAL CULTURE FROM \\ THE CONCEPT OF AN IDEAL WOMAN FOUND IN THE CONTEMPORARY WOMEN'S JOURNALS IN SERBIA}

\author{
ANALYSIS OF DISCOURSES FROM \\ THE COSMOPOLITAN AND BLIC ŽENA
}

\begin{abstract}
This paper analyses discourses on an "ideal woman" in modern Serbia ie the manner in which actual political culture is construed from representation of women in various ladies' journals. I have tried to define discourses produced by the Cosmopolitan and Blic Žena, pinpoint differences in the suggested concepts of womanhood and identify the manners in which such discourses and representations of women, their gender roles and relations, coincide with the wider social norms, stereotypes and practices. I have also analyzed the general impression left by these journals trying to categorize them into suggested "elementary prototypes" as defined by Neda TodorovićUzelac, primarily the prototypes/models of a traditional woman/female versus a rebelled, liberated woman (a feminist).
\end{abstract}

Key words: ideal woman concept, political culture, media discourse, discourse analysis, lifestyles, identity 